EESTI NSV TEADUSTE AKADEEMIA TOIMETISED. VI KOIDE BIOLOOGILINE SEERIA, 1957, NR. 4

ИЗВЕСТИЯ АКАДЕМИИ НАУК ЭСТОНСКОЙ ССР. ТОМ VI СЕРИЯ БИОЛОГИЧЕСКАЯ. 1957, № 4

\title{
OOOKULMADE SAGEDUS JA TUGEVUS KULTUURISTATUD MADALSOOS NING MINERAALMAAL
}

\author{
I. EISEN, \\ põllumajandusteaduste kandidaat
}

Öökülmade* sagedust ja tugevust (intensiivsust) meie kultuuristatud soodes on seni suhteliselt vähe uuritud. Veel vähem on vastavaid andmeid trükis avaldatud. Eesti NSV-s on pikema aja jooksul märgitud turvasmullal ja mineraalmaal öökülmade esinemisaega ning tugevust Eesti Maaviljeluse ja Maaparanduse Teadusliku Uurimise Instituudi Tooma katsebaasis. Käsitletav materjal pärineb aastaist 1934-1954 (viimane aasta kaasa arvatud). Kahjuks puuduvad 1945. aasta andmed mineraalmaa kohta, sest 1945. aastal vastavaid mõõtmisi ei tehtud.

Turvasmuld, kus toimusid mõõtmised, oli hästi kuivendatud. Tema botaanilises koostises esinesid peamiselt pilliroo ja tarna fragmendid, millede kõdunemisaste kõikus $30 \%$ piiris. Mineraalmaa vaatluspunkt (Tooma meteoroloogiajaama vaatlusväljak) asus metsast $150-200$ meetrit eemal raskel liivsavimullal. Meteoroloogia vaatlusväljaku lähema ümbruse pinnareljeef oli tasane, nõrga kallakuga põhja ning kagu suunas. Vaatlusväljakut ümbritsesid põllud. Nimetatud kohtades oli kõrgus merepinnast turvasmullal ca $78 \mathrm{~m}$ ja mineraalmaal ca $88 \mathrm{~m}$. Vaatlusväljakud paiknesid teineteisest ligikaudu $1 \mathrm{~km}$ kaugusel.

Arvestades turvasmulla termilis-füüsikalisi omadusi asetati miinimumtermomeetrid taimkatteta pinnast $2 \mathrm{~cm}$ kõrgusele, et mõõta öökülma ajal madalamat temperatuuri. Nii toimiti tol ajal ka naaberriikide soojaamades. Mineraalmaal paigutati termomeetrid vahetult kobestatud ja taimedeta hoitud pinnale, milline paigutus oli tingitud hüdrometeoroloogilistest eeskirjadest. Selline erinev termomeetrite paigutus teataval määral segab mõõtmistulemuste kõrvutamist, kuid - nagu 1951. ja 1952. aastal teostatud kontrollmõõtmised näitasid - ei keela see turvasmulla ja mineraalmaa öökülmade sageduse ning tugevuse võrdlemist.

Öökülmade esinemisaja tundmaõppimiseks esitatakse joonisel 1 turvasmulla ja joonisel 2 mineraalmaa kohta vastav materjal. Nagu nähtub, võivad öökülmad turvasmullal esineda Toomal kõigis taimekasvukuudes, kusjuures kõige vähem on miinustemperatuure juuli II ja III dekaadis. Mineraalmaal kestis külmavaba periood juuni II dekaadist kuni augusti III dekaadini. Seega ligikaudu $60-70$ päeva pikkusel ajavahemikul ei ole mineraalmaal 20 aasta jooksul esinenud temperatuurilangusi $0^{\circ}$-ni või alla selle.

Et ajaliselt paremini iseloomustada öökülmade sagedust, on joonistel 1 ja 2 märgitud nende esinemine taimekasvu dekaadidel ${ }^{* *}$. Joonistel 1 ja 2 on antud veel öökülmade sagedus dekaadide kaupa protsentides nende üld-

* Oökülmadeks nimetatakse maapinna ja maapinna lähedaste ōhukihtide lühiajalisi temperatuuri langusi perioodil, mil ööpäevane keskmine temperatuur on üle $0^{\circ}$.

** Dekaadid ajavahemikul 1. maist kuni 30. septembrini. 


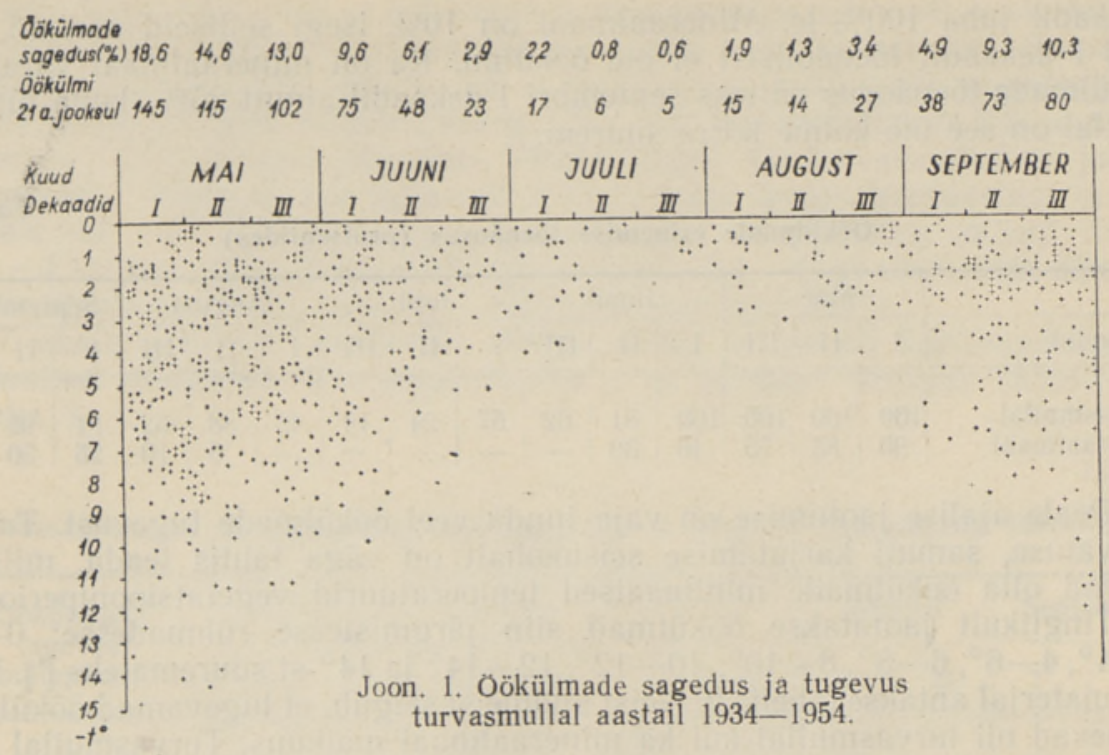

arvust. Niisugune analüüs aitab lähemalt pilku heita turvasmulla ja mineraalmaa öökülmade ajalisele jaotumisele. Näiteks ilmneb, et mineraalmaal langeb üle $50 \%$ öökülmajuhtumeid maikuu I ja II dekaadile, kuna turvasmullal oli neid sel ajal ainult vähe üle $30 \%$. Järelikult jaotuvad mineraalmaa öökülmad peamiselt vegetatsiooni algus- ja lõpp-perioodile. Turvasmullal pikenevad kevadised ja sügisesed öökülmade perioodid 15-20 päeva võrra, kusjuures miinustemperatuuride võimalus esineb isegi kõige soojematel suvekuudel.

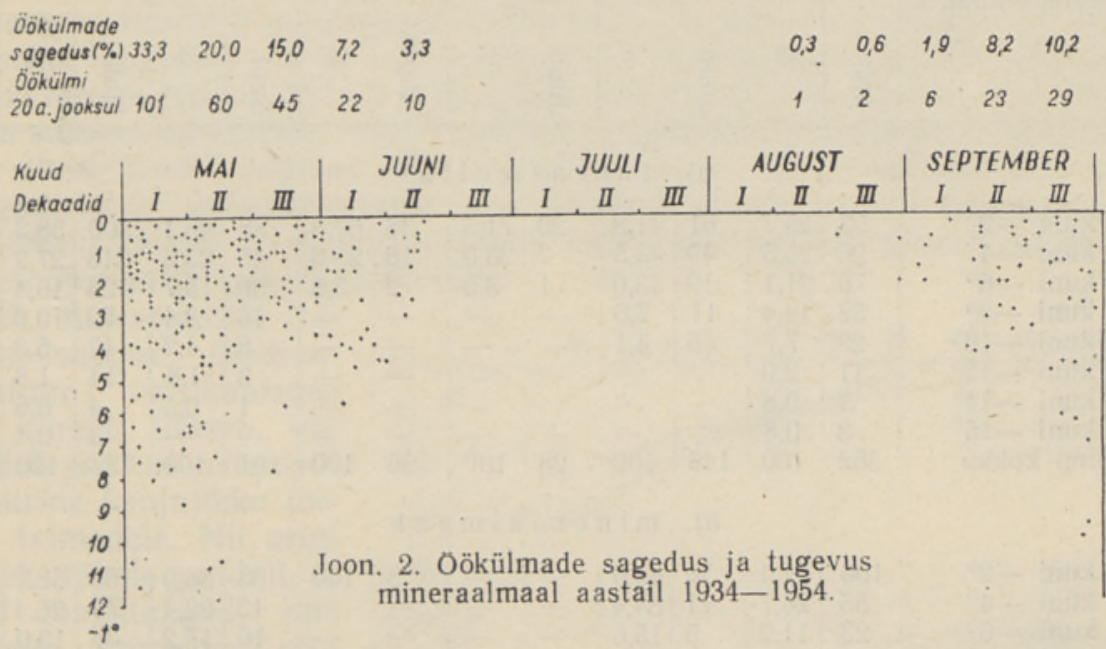

Turvasmullal arvutati 21 -aastase ja mineraalmaal 20 -aastase vaatlusrea järgi öökülmade esinemisvõimalused taimekasvuperioodide kohta (tabel 1). Nagu need andmed näitavad, esinevad öökülmad turvasmullal kevadel kuni juuni II dekaadini $100 \%$-lise tõenäosusega. Väikseim tõenäosus $(14 \%)$ on juuli III dekaadil.

Turvasmullal on juba augusti III dekaadil suur öökülmade esinemise võimalus, nimelt $62 \%$. Septembri I dekaadil see tõuseb $81 \%$-le ning III 
dekaadil juba $100 \%$-le. Mineraalmaal on $10 \%$ isegi selliseid aastaid, kus mai I dekaadil tõenäoliselt ei ole öökülmi. Ka on mineraalmaal varajaste öökülmade tõenäosus näiteks septembri I dekaadil ainult 25\%, kuna turvasmullal on see üle kolme korra suurem.

Oökülmade esinemise tõenäosus (protsentides)

Tabel 1

\begin{tabular}{|c|c|c|c|c|c|c|c|c|c|c|c|c|c|c|c|}
\hline \multirow[b]{2}{*}{ Dekaadid } & \multicolumn{3}{|c|}{ Mai } & \multicolumn{3}{|c|}{ Juuni } & \multicolumn{3}{|c|}{ Juuli } & \multicolumn{3}{|c|}{ August } & \multicolumn{3}{|c|}{ September } \\
\hline & I & II & III & I & II & III & I & II & III & I & II & III & I & II & III \\
\hline $\begin{array}{l}\text { Turvasmullal } \\
\text { Mineraalmaal }\end{array}$ & $\begin{array}{r}100 \\
90\end{array}$ & $\begin{array}{r}100 \\
85\end{array}$ & $\begin{array}{r}100 \\
75\end{array}$ & $\begin{array}{r}100 \\
40\end{array}$ & $\begin{array}{l}81 \\
30\end{array}$ & $\underline{62}$ & 57 & 24 & 14 & 43 & $\begin{array}{r}38 \\
5\end{array}$ & $\begin{array}{l}62 \\
10\end{array}$ & $\begin{array}{l}81 \\
25\end{array}$ & $\begin{array}{l}95 \\
50\end{array}$ & $\begin{array}{r}100 \\
65\end{array}$ \\
\hline
\end{tabular}

Peale ajalise jaotumise on vaja tunda veel öökülmade tugevust. Taimekasvatuse, samuti karjatamise seisukohalt on väga tähtis teada, millised vôivad olla öökülmade minimaalsed temperatuurid vegetatsiooniperioodil.

Tinglikult jaotatakse öökülmad siin järgmistesse rühmadesse: $0-2^{\circ}$, $2-4^{\circ}, 4-6^{\circ}, 6-8^{\circ}, 8-10^{\circ}, 10-12^{\circ}, 12-14^{\circ}$ ja $14^{\circ}$-st suuremateks [ $\left.{ }^{1}\right]$. Vlastav materjal antakse tabelis 2 . Neist andmeist selgub, et tugevamad öökülmad esinevad nii turvasmullal kui ka mineraalmaal maikuus. Turvasmullal võib sel ajal üksikutel juhtudel temperatuur langeda kuni $-15^{\circ}$-ni. Mineraalmaal ei ole maikuus 20 aasta jooksul temperatuur langenud alla $-12^{\circ}$.

Tabel 2

Orkülmade jaotumine tugevuse järgi turvasmullal ja mineraalmaal aastail 1934-1954

\begin{tabular}{|c|c|c|c|c|c|c|c|c|c|c|c|c|c|}
\hline \multirow{2}{*}{$\begin{array}{l}\text { Oǒkülmade } \\
\text { tugevusrühmad }\end{array}$} & \multicolumn{10}{|c|}{ Oökülmade sa } & \multicolumn{2}{|c|}{$\begin{array}{l}\text { Oökülmi } \\
\text { 1. maist } \\
30 \text {. sep- } \\
\text { tembrini }\end{array}$} & \multirow{2}{*}{ 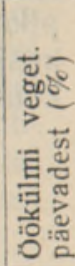 } \\
\hline & $\tilde{\sum}^{\bar{\pi}}$ & $\%$ & 哥 & $\%$ & 咅 & $\%$ & 总 & $\%$ & 范 & $\%$ & 羙 & $\%$ & \\
\hline
\end{tabular}

a) turvasmu11a1

$\begin{aligned} & 0^{\circ} \text { kuni }-2^{\circ} \\ &-2^{\circ} \text { kuni }-4^{\circ} \\ &-4^{\circ} \text { kuni }-6^{\circ} \\ &-6^{\circ} \text { kuni }-8^{\circ} \\ &-8^{\circ} \text { kuni }-10^{\circ} \\ & 10^{\circ} \text { kuni }-12^{\circ} \\ &-12^{\circ} \text { kuni }-14^{\circ} \\ &-14^{\circ} \text { kuni }-15^{\circ} \\ & \text { Ookkulmi kokku }\end{aligned}$

\begin{tabular}{r|r|}
93 & 25,7 \\
96 & 26,5 \\
76 & 21,1 \\
52 & 14,4 \\
28 & 7,7 \\
11 & 3,0 \\
3 & 0,8 \\
3 & 0,8 \\
362 & 100
\end{tabular}

\begin{tabular}{r|r|r|r|r}
61 & 41,8 & 20 & 71,5 & 38 \\
49 & 33,5 & 7 & 25,0 \\
19 & 13,0 & 1 & 3,5 \\
11 & 7,6 & - & - \\
6 & 4,1 & - & - \\
- & - & - & - \\
$\overline{-}$ & $\overline{-}$ & - & - \\
\hline$\overline{46}$ & 100 & $\overline{28}$ & $\overline{100}$
\end{tabular}

b) minera a $1 \mathrm{ma}$ a 1 $0^{\circ}$ kuni $-2^{\circ}$
$-2^{\circ}$ kuni $-4^{\circ}$
$-4^{\circ}$ kuni $-6^{\circ}$
$-6^{\circ}$ kuni $-8^{\circ}$
$-8^{\circ}$ kuni $-10^{\circ}$
$-10^{\circ}$ kuni $-12^{\circ}$
$-12^{\circ}$ kuni $-14^{\circ}$
$-14^{\circ}$ kuni $-15^{\circ}$

Oökülmi kokku

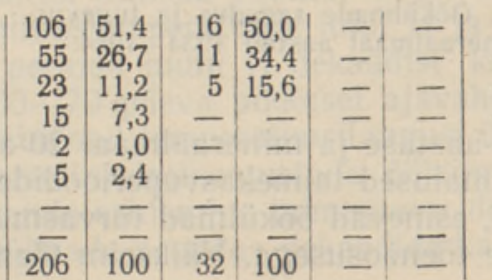

\begin{tabular}{r|r|}
38 & 67,8 \\
16 & 28,6 \\
2 & 3,6 \\
- & - \\
- & $\overline{-}$ \\
$\overline{-}$ & $\overline{-}$ \\
$\overline{5}$ & $\overline{-}$ \\
\hline 6 & 100
\end{tabular}

\begin{tabular}{r|r|r|r|r}
88 & 46,1 & 300 & 38,3 & 9,4 \\
45 & 23,5 & 213 & 27,2 & 6,6 \\
30 & 15,7 & 128 & 16,4 & 4,0 \\
16 & 8,4 & 79 & 10,0 & 2,5 \\
8 & 4,2 & 42 & 5,3 & 1,3 \\
3 & 1,6 & 14 & 1,8 & 0,4 \\
1 & 0,5 & 4 & 0,6 & 0,1 \\
$\overline{1}$ & $\overline{3}$ & 3 & 0,4 & 0,1 \\
191 & 100 & 783 & 100 & 24,4
\end{tabular}

\begin{tabular}{r|r|r|r|r}
33 & 56,9 & 158 & 52,7 & 5,2 \\
13 & 22,4 & 79 & 26,4 & 2,5 \\
10 & 17,2 & 38 & 13,0 & 1,2 \\
2 & 3,5 & 17 & 5,6 & 0,6 \\
- & - & 2 & 0,7 & 0,1 \\
- & - & 5 & 1,6 & 0,2 \\
- & - & - & - & - \\
\hline$\overline{58}$ & $\overline{-}$ & $\overline{-}$ & $\overline{-}$ & - \\
\hline
\end{tabular}

Väga tähtis on teada miinustemperatuuride suurust juunis, sest sel ajal hakkavad intensiivselt kasvama paljud külmaõrnad põllu- ning aiakultuurid. 
Märgitagu siinkohal, et öökülmad temperatuuriga alla $-4^{\circ}$ ei ole turvasmuldadel palju kahjustanud vagudel kasvavaid noori kartulitaimi. Seepärast võrreldakse järgnevais näiteis $-4^{\circ}$-st tugevamate öökülmade sagedust. Nii esines juunis öökülmi temperatuuriga alla $-4^{\circ}$ turvasmullal $24,7 \%$ ja mineraalmaal $15,6 \%$ kõigist juhtudest. Teisiti öeldes: kui turvasmullal oli juunis keskmiselt 7 öökülma, siis ligikaudu $2(1,7)$ juhul langes temperatuur madalamale kui $-4^{\circ}$. Mineraalmaal oli samal ajal 1,6 öökülma, millest $15,6 \%$ olid $-4^{\circ}$-st suuremad. Septembris oli turvasmullal $-4^{\circ}$-st suuremaid öökülmi nende üldarvust $30,4 \%$, seevastu mineraalmaal vaid $20,7 \%$.

7 aasta pikkusel perioodil (1948-1954) esinenud öökülmadeaegsed keskmised miinimum-ôhutemperatuurid $2 \mathrm{~m}$ kõrgusel antakse rühmitatult tabelis 3 .

Tabel 3

Oökülmadeaegsed miinimum-õhutemperatuurid $2 \mathrm{~m}$ kõrgusel (ajavahemik 1948-1954)

\begin{tabular}{|c|c|c|c|c|c|c|c|c|c|c|}
\hline \multirow{2}{*}{$\begin{array}{l}\text { Oökülmade } \\
\text { tugevus } \\
\text { mullapinnal }\end{array}$} & \multicolumn{2}{|c|}{ Mai } & \multicolumn{2}{|c|}{ Juuni } & \multicolumn{2}{|c|}{ Juuli } & \multicolumn{2}{|c|}{ August } & \multicolumn{2}{|c|}{ September } \\
\hline & $\mathrm{T}$ & M & $\mathrm{T}$ & M & $\mathrm{T}$ & $M$ & $\mathrm{~T}$ & M & $\mathrm{T}$ & $M$ \\
\hline $\begin{aligned} 0^{\circ} & \text { kuni }-2^{\circ} \\
-2^{\circ} & \text { kuni }-4^{\circ} \\
-4^{\circ} & \text { kuni }-6^{\circ} \\
-6^{\circ} & \text { kuni }-8^{\circ} \\
-8^{\circ} & \text { kuni }-10^{\circ} \\
-10^{\circ} & \text { kuni }-12^{\circ}\end{aligned}$ & $\begin{array}{r}2,3 \\
1,7 \\
0,1 \\
-2,7 \\
-3,5 \\
-6,6\end{array}$ & $\begin{array}{l}-0,3 \\
-1,4 \\
- \\
- \\
-\end{array}$ & $\begin{array}{r}3,6 \\
2,6 \\
0,6 \\
-0,9 \\
-3,0 \\
-\end{array}$ & $\begin{array}{l}\overline{-} \\
\overline{-} \\
\overline{-}\end{array}$ & $\begin{array}{l}5,1 \\
2,8 \\
- \\
- \\
-\end{array}$ & $\begin{array}{l}- \\
\overline{-} \\
-\end{array}$ & $\begin{array}{l}3,3 \\
2,3 \\
0,7 \\
- \\
- \\
-\end{array}$ & $\begin{array}{l}\bar{z} \\
\overline{-} \\
\overline{-}\end{array}$ & $\begin{array}{r}2,8 \\
1,4 \\
0,7 \\
-2,5 \\
-4,0 \\
-\end{array}$ & $\begin{array}{l}-0,8 \\
= \\
= \\
-\end{array}$ \\
\hline
\end{tabular}

Mårkus: $\mathrm{T}$ - turvasmullal; $\mathrm{M}$ - mineraalmaal.

Neist selgub, et turvasmullal keskmised öökülmadeaegsed miinimumõhutemperatuurid 2 m kõrgusel olid positiivsed seni, kuni maapinnal temperatuur ei langenud $-4 \mathrm{ja}-6^{\circ}$-st allapoole. Suuremate temperatuurilanguste korral langes temperatuur $2 \mathrm{~m}$ körgusel keskmiselt seda rohkem allapoole $0^{\circ}$, mida suurem oli öökülm. Mineraalmaal langes öökülmadeaegne õhutemperatuur (keskmiselt võetuna) isegi sel juhul alla $0^{\circ}$, kui maapinnal olid ainult nõrgad, $0-2^{\circ}$ miinustemperatuurid. Viimane asjaolu näitab turvasmuldade suhteliselt väikest soojajuhtivust, mis omakorda takistab öötundidel õhukihtide soojenemist maapinna lähedal.

Et turvasmullal öökülmadeaegne õhutemperatuur vertikaalsuunas kiiresti tõuseb, vähendab see miinustemperatuuride kahjulikku toimet taimedele. Nii ongi näiteks tähele pandud, et need maisitaimed, mis teistega võrreldes olid mikroreljeefilt $10-28 \mathrm{~cm}$ kõrgemal, kasvasid paremini just soodsamate termiliste tingimuste

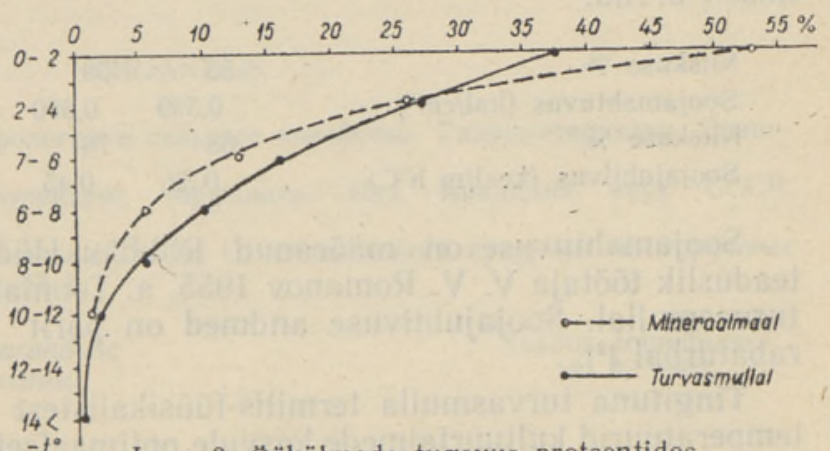

Joon. 3. Oökülmade tugevus protsentides nende üldarvust. tõttu [ [?].

Tabelis 2 on veel toodud öökülmade hulk, rühmitatuna kogu vegetatsiooniperioodi kohta Andes iga rühma arvud protsentides öökülmade üld- 
arvust ja kujutades neid andmeid graafiliselt, saadakse ülevaade suvistest miinustemperatuuride võimalikest tugevustest (joon. 3).

Öökülmade tugevusrühmade suhtes esineb seaduspärasus, mida näitab kõverjoon joonisel 3. Mineraalmaa öökülmi kujutava joone tõusunurk valdavamas osas on tunduvalt väiksem, võrreldes turvasmulla öökülmi kujutava joonega. Järelikult esinevad turvasmullal öökülmade ajal suuremad ning järsemad temperatuurilangused kui mineraalmaal.

Jälgides $-4^{\circ}$ väiksemaid öökülmi selgub, et nad moodustavad üldarvust turvasmullal $65,5 \%$ ja mineraalmaal $79,1 \%$. Seega võivad mineraalmaa öökülmadest ligikaudu $20 \%$ ja turvasmullal ca $35 \%$ olla tõenäoliselt tugevamad $-4^{\circ}$-st.

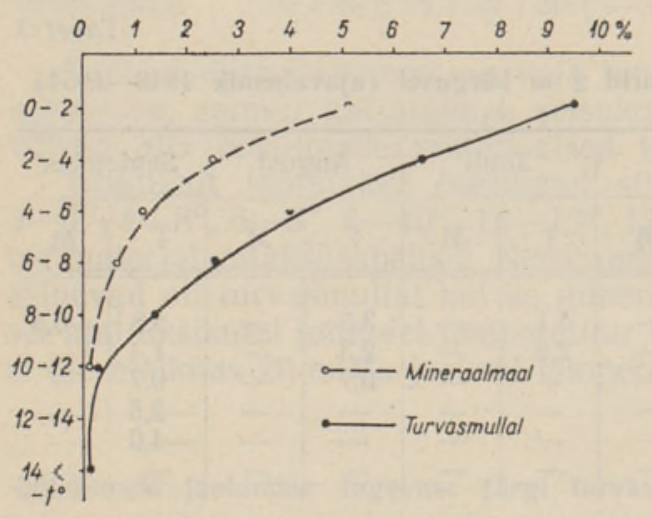

Joon. 4. Öökülmade protsent vegetatsioonipäevadest.

Et näitlikult esile tuua öökülmade võimalikku tugevust turvasmullal ja mineraalmaal, esitatakse need andmed graafiliselt joonisel 4 . Nähtub, et turvasmullal võib olla üle $9 \%$ selliseid vegetatsioonipäevi, kus öökülma tugevus on $0^{\circ}$ kuni $-2^{\circ}$. Nende päevade hulk mineraalmaal on ligikaudu $5 \%$. Teisiti öeldes: 153 vegetatsioonipäeval (1. V-30. IX) on turvasmullal keskmiselt 14 ja mineraalmaal 8 sellist öökülmavõimalust, kus tempenatuur ei lange $-2^{\circ}$ allapoole.

Veelgi suuremaks muutub erinevus turvasmulla ja mineraalmaa öökülmade puhul, mis on $4-6^{\circ}$ ja $6-8^{\circ}$ piiris. Nii näiteks $6-8^{\circ}$ öökülmi võib turvasmullal esineda taimekasvupäevadest keskmiselt $2,5 \%$, mineraalmaal aga kõigest $0,6 \%$. $-10^{\circ}$ tugevamaid öökülmi esineb vähem kui $0,5 \%$ taimekasvupäevadest, kuid ka need öökülmad, nagu nähtub tabelisł 2 , on turvasmullal ülekaalus.

Oökülmade tugevus turvasmullal sõltub kuivenduse intensiivsusest, s. t. mulla niiskusest. Kui põhjavesi ei ole kuivendusega viidud teatud sügavusele, hoiab kapillaarvee tõus turvasmulla seda niiskema, mida kõrgem on põhjaveeseis. Niiskuse tõusuga suureneb turvasmulla soojamahtuvus, veel enam suureneb aga tema soojajuhtivus. Seda vahekorda aitavad selgitada järgmised arvud.

$\begin{array}{lcccccc}\text { Niiskuse \% } & 53 & 59 & 70 & 80 & \\ \left.\text { Soojamahtuvus (kal } / \mathrm{cm}^{3}\right) & 0,599 & 0,670 & 0,778 & 0,843 & \\ \text { Niiskuse \% } & 68 & 76 & 82 & 88 & 93 \\ \left.\text { Soojajuhtivus (kcal } / \mathrm{m} \mathrm{h}^{\circ} \mathrm{C}\right) & 0,32 & 0,45 & 0,64 & 0,83 & 1,01\end{array}$

Soojamahtuvuse on määranud Riikliku Hüdroloogia Instituudi vanem teaduslik töötaja V. V. Romanov 1955. a. Toomal vähekõdunenud madalsoo turvasmullal. Soojajuhtivuse andmed on pärit S. N. Tjuremnovi katsest rabaturbal $\left[{ }^{2}\right]$.

Tingituna turvasmulla termilis-füüsikalistest omadustest on miinimumtemperatuurid kultuurtaimede kasvule optimaalsetes niiskustingimustes alati madalamad kui halvemates kuivendustingimustes. Seda muidugi sellepärast, et niiskuse vähenedes väheneb tunduvalt turvasmulla soojajuhtivus.

Olgu märgitud, et taimekasvukuudel on osutunud optimaalseks künnikihi niiskuseks vähe- kuni keskmiseltkõdunenud turvasmullal keskmiselt 
55-65\% maksimaalsest veemahutavusest. Selline mullaniiskus saavutatakse siis, kui keskmine põhjaveeseis on $75-80$ cm-st kõrgemal.

Järgnevalt esitataksegi näide turvasmulla niiskuse mõjust öistele miinimumtemperatuuridele taimedeta pinnal.

\begin{tabular}{|c|c|c|}
\hline \multirow{2}{*}{$\begin{array}{l}\text { Mõōtmise } \\
\text { aeg }\end{array}$} & \multirow{2}{*}{$\begin{array}{l}\text { Körgus maa- } \\
\text { pinnast }(\mathrm{cm})\end{array}$} & $\begin{array}{l}\text { Künnikihi niiskus } \\
\text { mahuprotsentides }\end{array}$ \\
\hline & & $\begin{array}{ccc}58 & 74 & 81 \\
\text { Miinimumtermomeetri } & \text { näidud }\end{array}$ \\
\hline $\begin{array}{lll}25 . & \text { VI } 1955 \\
29 . & \text { VI } 1955\end{array}$ & $\begin{array}{l}2 \\
2\end{array}$ & $\begin{array}{r}+17,9 \\
-3,0\end{array}$ \\
\hline
\end{tabular}

Luues kultuurtaimedele madalsoodes paremaid mullastikutingimusi, halvenevad teisest küljest seal pinnase termilised tingimused, kuid öökülmade kahjustus heintaimedele ja enamikule teraviljakultuuridest on siiski väike või isegi tühine võrreldes selle kahjuga, mida tekitab neile kõrge põhjavesi, s. t. puudulik kuivendus.

Toomal ei ole heina-, talirukki- ja söödakapsakultuurid hästikuivendatud turvasmullal öökülmade käes nimetamisväärselt kannatanud, kaera ja odra orast aga kahjustasid $-8^{\circ}$-st tugevamad öökülmad. Seejuures orase lehed hävisid kas täielikult või osaliselt, kuid taimed jäid ellu. Nende kasv algas hoogsamalt jälle 5 kuni 8 päeva pärast. Nii hiliste kui ka varajaste öökülmade tagajärjel oli rohkem kahjustusi ja saak vähenes tunduvalt kartulil, - maisil, kurgil, tomatil ja mõningal määral isegi suhkrupeedil. Kapsa-, porgandi-, sibula-, herne- ja päevalilletaimed ei ole seniste tähelepanekute järgi suviste miinustemperatuuride käes palju kannatanud. Vähem tundlikud öökülmadele olid veel kaalika-, naeri- ja söödapeeditaimed.

Võrreldes mineraalmaaga oli turvasmullal järelikult öökülmi üle poole rohkem ja esines tunduvalt suuremaid temperatuuri langusi. Kevadiste hiliste ja sügiseste varajaste öökülmade mõjul on turvasmullal vegetatsiooniperioodi pikkus külmaõrnadel taimedel juhuslik ning alati lühem kui mineraalmaal. Ka võivad üksikud südasuvised öökülmad põhjustada tunduvaid vigastusi või isegi hävitada külmaõrnu kultuure. Mis puutub öökülmade vastu võitlemisse, siis praegu on selleks abinõud väga piiratud ja kulukad. Seepärast tuleb turvasmullal kasvatada peamiselt külmale vastupidavamaid taimeliike, eeskätt kultuurniidu- ja karjamaataimi.

\section{KIRJANDUS}

1. Максимов С. А., Метеорология и сельское хозяйство. Гидрометеоиздат, Ленинград 1952.

2. Пьявченко Н. И., Бугристые торфяники. Изд. Академии наук СССР, Москва 1955.

3. С м и рнов А. В. и Хи т ров а О. В., О возделывании кукурузы на торфяных почвах. «Земледелие» 1956, № 4.

Eesti Maaviljeluse ja Maaparanduse Teadusliku Uurimise Instituut
Saabus toimetusse

15. V 1956 


\title{
О ЧАСТОТЕ И ИНТЕНСИВНОСТИ ЗАМОРОЗКОВ НА ОКУЛЬТУРЕННЫХ НИЗИННЫХ БОЛОТАХ И НА МИНЕРАЛЬНЫХ ПОЧВАХ
}

\author{
И. А. Эйзен, \\ кандндат сельскохозяйственных наук
}

Резюме

Условия выращивания культур на осушенных торфяных почвах значительно отличаются от условий, имеющих место на минеральных почвах. Одним из важнейших факторов, обусловливающих выбор сельскохозяйственных культур для выращивания на торфяных почвах, являются ночные заморозки.

В Эстонской ССР на Опытной станции Тоома в течение многих лет (1934-1954rг.) велись наблюдения за сроками наступления и интенсивностью заморозков. По этим данным установлены различия в микроклиматических условиях на минеральных и торфяных почвах в течение вегетационного периода. Основное различие заключается в наличии поздних летних заморозков, наблюдаемых на торфяных почвах.

Установлено, что заморозки на торфяных почвах могут наблюдаться в течение всего вегетационного периода (с 1 мая по 30 сентября). Напротив, на минеральных почвах заморозки отсутствуют со второй декады июня по третью декаду августа. На торфяных почвах заморозки в течение вегетационного периода наблюдались в среднем 37,3 раза, а на минеральных почвах - 14,9 раза.

Вероятность наступления заморозков на торфяных почвах до второй декады июня составляет 100\%. Наименьшая вероятность $(14 \%)$ падает на третью декаду июля. Начиная с третьей декады сентября вероятность наступления ранннх осенних заморозков на торфяных почвах увеличивается до $100 \%$. На минеральных почвах наблюдалось $10 \%$ лет, в которые уже в первой декаде мая не было заморозков.

В пернод заморозков температура воздуха в приземном слое торфяных и минеральных почв была различной. Так, на высоте 2 м на окультуренном болоте температура была в среднем положительной до тех пор, пока температура поверхности почвы не понизилась до $-4 \ldots-6^{\circ}$. На минеральных же почвах температура воздуха на высоте 2 м при заморозках была ниже $0^{\circ}$ даже тогда, когда температура почвы составляла от 0 до $-2^{\circ}$.

Анализ интенсивности заморозков показал, что в течение вегетационного периода (c 1 V по 30 IX) на торфяных почвах наблюдается свыше $9 \%$ дней, когда интенсивность заморозков колеблется в пределах от 0 до $-2^{\circ}$. Соответствующее количество дней с заморозками на минеральных почвах составило приблизительно $5 \%$. Еще более значительны расхождения при заморозках с интенсивностью от -4 до $-6^{\circ}$ и от -6 до $-8^{\circ}$. Так, например, на торфяных почвах за весь вегетационный период заморозки интенсивностью $-6 \ldots-8^{\circ}$ наблюдались в течение $2,5 \%$ дней, а на минеральных почвах - только $0,6 \%$ дней.

Заморозки с температурой $-10^{\circ}$ наблюдались меньше, чем в $0,5 \%$ случаев, причем большинство из них падает на торфяные почвы.

Прнчинами частых и значительных по интенсивности заморозков на осушенных окультуренных низинных болотах являются физические свойства торфяных почв. При достаточном осушении, в тот период, когда нет осадков, происходит высыхание поверхностного слоя торфяных почв (на $3-4 \mathrm{~cm}$ ) до степени влажности воздуха. Этот слой является одним из важнейших факторов, мешающих нагреванию припочвенного слоя воздуха за счет тепла, поступающего из почвы в ночное время.

На полях, где осушение недостаточно интенсивно и влажность торфяных почв велика, интенсивность заморозков уменьшается.

Из изложенного выше следует, что вследствие поздних (весенних) и ранних (осенних) заморозков длительность вегетационного периода для чувствительных к заморозкам растений на торфяных почвах короче, чем на минеральных почвах. Отдельные летние заморозки могут повреждать и даже уничтожать плохо переносящие заморозки сельскохозяйственные культуры (картофель, кукурузу, огурщы).

На торфяных почвах необходимо выращивать в основном устойчивые к заморозкам культуры - в первую очередь многолетние травы, озимую рожь, ячмень, кормовую капусту, подсолнечник, вико-овсяную смесь и другие. 


\section{OBER NACHTFROSTE AUF KULTIVIERTEM FLACHMOOR UND AUF MINERALBODEN}

\section{Eisen}

\section{Zusammenfassung}

In der Moor-Versuchsstation Tooma sind in den Jahren 1934-1954 Messungen der Nachtfröste auf Torf- und Mineralböden angestellt worden.

Die Analyse der Messergebnisse zeigte, dass auf Torfboden die Nachtfröste während der ganzen Vegetationsperiode (vom 1. Mai bis zum 30. September) vorkommen können. Auf Mineralböden dagegen ist die Zeitspanne von der zweiten.Junidekade bis zur dritten Augustdekade frostfrei.

Die durchschnittliche Häufigkeit der Nachtfröste war in der. Vegetationsperiode auf Torfböden 37,3 und auf Mineralböden 14,9 Fälle.

Bis zur zweiten Dekade des Monats Juni kamen Nachtfröste auf Torfböden mit $100 \%$-ger Wahrscheinlichkeit vor. In der dritten Dekade des Juli war ihre Wahrscheinlichkeit geringer, nämlich $14 \%$. Von der dritten Septemberdekade an stieg aber die Wahrscheinlichkeit der Nachtfröste auf Torfböden bereits auf $100 \%$. Auf Mineralböden hingegen gab es sogar $10 \%$ solcher Jahre, wo schon die erste Dekade des Monats Mai frostfrei war.

Die Analyse der Froststärke ergab, dass es auf Torfböden über 9\% Vegetationstage geben kann, wo der Nachtfrost zwischen $0^{\circ}$ und $-2^{\circ}$ schwankt. Auf Mineralböden ist die Zahl solcher Tage ca $5 \%$. Noch grösser ist der Unterschied für Nachtfröste unter $-4^{\circ}$. So ist z. B. die Häufigkeit der Nachtfröste zwischen $6^{\circ}$ und $8^{\circ}$ auf Torfböden $2,5 \%$ aller Vegetationstage, auf Mineralböden aber nur $0,6 \%$.

Infolge der Früh- und Spätfroste verkürzt sich auf Torf́böden die Vegetationsperiode frostempfindlicher Pflanzen; sie wird zufällig und bleibt immer kürzer als auf Mineralböden. Auch können vereinzelte Frostfälle im Hochsommer beträchtlichen Schaden antun oder gar zartere Kulturen (Kartoffel, Mais, Gurke usw.) zugrunde richten.

Deswegen sind auf Torfböden weniger empfindliche Pflanzen anzubauen: vor allem mehrjährige Kräuter, sodann Winterroggen, Gerste, Mischkorn, Kohl, Sonnenblume usw.

Institut für Ackerbau und Melioration der Estnischen SSR
Eingegangen am 15. Juni 1956 